\title{
Communications
}

\section{Efficient and General One-pot Synthesis of $\beta$-Chloro- $\beta$-trifluoromethylated Enones from 3,3,3-Trifluoropropyne}

\author{
Sung Lan Jeon, Dae Ho Kim, Jang Bae Son, and In Howa Jeong \\ Department of Chemistry, Yonsei Lniversity, Honju, Gangwon 220-710, Korea. ${ }^{\star}$ E-mail: jeongihanonseiackr \\ Received September 20,2006
}

Key Words : 3,3.3-Triflıoropropyne. Weinreb amide. Hydrochlorination. $\beta$-Chloro- $\beta$-trifluoromethylated enones

Trifluoromethylated compounds which can be easily transformed to other functionality have been receiving nuch attention as building blocks because of their potential to give a variety of trifluoromethylated analogs of bioactive and material molecules. ${ }^{1-3}$ Especially $\beta$-chloro- $\beta$-trifluoromethylated enones are very useful building blocks to provide trifluoromethyl substituted heterocycles such as pyrazoles. isoxazoles and pyrimidines. ${ }^{+7}$ Several methods for the preparation of $\beta$-chloro- $\beta$-trifluoromethylated enones have been reported in the previous literatures, ${ }^{6-8-\bar{y}}$ but the previous methods have some drawbacks such as formation of regioisomers, lack of generalization and low yield preparation. Eguchi et al. reported that addition of 1.1,1-trichloro-2.2,2trifluoroethane to carbon-carbon double bond of trimethylsilyl enol ethers in the presence of copper(I) chloride, followed by dehydrochlorination with triethylamine, afforded $\beta$-chloro- $\beta$-trifluoromethylated enones in moderate yields." Vilsmeier reagent which was formed from the reaction of dimethylformamide with oxalyl chloride was reacted with trifluoromethylated 1.3-diketone ${ }^{6}$ or ketone ${ }^{9}$ to provide $\beta$-chloro- $\beta$-trifluoromethylated enones in moderate yield, along with other regioisoner. In this communication. we wish to describe an efficient and general one-pot synthesis of $\beta$-chloro- $\beta$-trifluoromethylated enones from 3.3.3trifluoropropyne.

Recently, we reported that trifluoropropynyllithium was reacted with $N$-methoxy- $N$-nethylbenzanide (Weinreb benzamide) ${ }^{10}$ at $-78^{\circ} \mathrm{C}$. followed by waming to $0^{\circ} \mathrm{C}$ and quenching with water to give $E$ and $Z$ isomeric mixture of $\beta$ trifluoromethyl enaminone in good yield." If the same reaction intermediate [I] would be treated with aqueous $\mathrm{HCl}$, $N$-methosy- $N$-methylamine formed in the reaction will be neutralized with $\mathrm{HCl}$ and thus chloride ion existed in the reaction mixture will react with $\beta$-trifluoromethylated y'none [II] to provide $\beta$-chloro- $\beta$-trifluoromethy lated enones $1 \mathrm{via}$ allenol [III] (Scheme 1). When trifluoropropynyllithium was reacted with Weinreb benzamide under the same reaction condition and then quenching with $3 \mathrm{~N} \mathrm{HCl}$, however. trifluoromethylated 1.3-diketone 2a was obtained as an only product. The formation of $\mathbf{2} \mathbf{a}$ can be postulated to be due to the reaction of ynone [II] with $\mathrm{H}_{2} \mathrm{O}$ first instead of chloride ion under dilute acidic condition. This result indicates that concentration of $3 \mathrm{~N} \mathrm{HCl}$ may not be enough to give 1a and thus we decided to increase the concentration of $\mathrm{HCl}$. Treatment of intermediate [I] with $6 \mathrm{~N} \mathrm{HCl}$ resulted in the formation of 1 a in $95 \%$ yield as $E$ and $Z$ isomeric mixture $(E Z=54 / 46)$. A longer reaction time with higher concentration than $6 \mathrm{~N} \mathrm{HCl}$ afforded the same result. Assignment of $E$ and $Z$ isomers of 1 a was made by the comparison of chemical shift of authentic sample in ${ }^{19} \mathrm{~F}$ and ${ }^{l} \mathrm{H}$ NMR spectroscopy. ${ }^{8}$ Weinreb benzamides having substituent such as methyl. methoxy, fluoro, chloro, bromo and trifluoromethyl group on para position of benzene ring also provided the corresponding enones $\mathbf{1 b}-\mathbf{1 g}$ in $\mathbf{9 2 - 9 4 \%}$ y ields under the same reaction condition. However, the use of $10 \mathrm{~N} \mathrm{HCl}$ was required to give the corresponding enones $1 \mathbf{h}-1 \mathbf{n}$ in the case of Weinreb benzanides having substituent on ortho or meta position of benzene ring. Weinreb naphthalenamide and Weinreb furananide. Weinreb cyclohexanamide also afforded the corresponding enone 10 in $81 \%$ yield. Results of these reactions are summarized in Table 1 .<smiles>CN(C)C(=O)c1ccccc1</smiles>

[I]
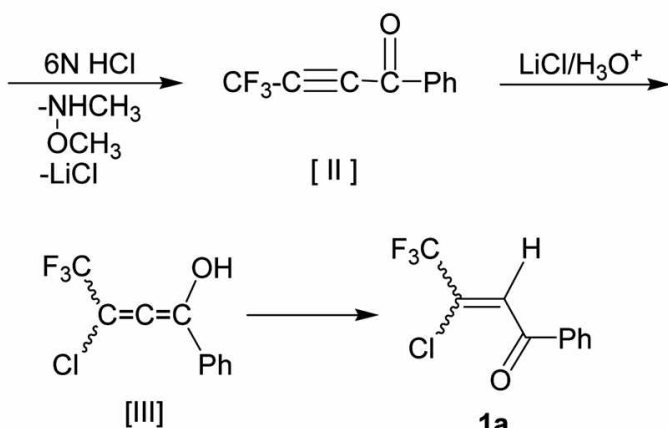

Scheme 1 
Table 1. Preparation of $\beta$-chloro- $\beta$-tritluoromethylated enones 1

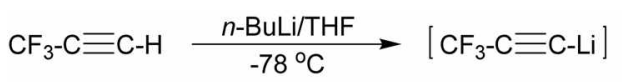

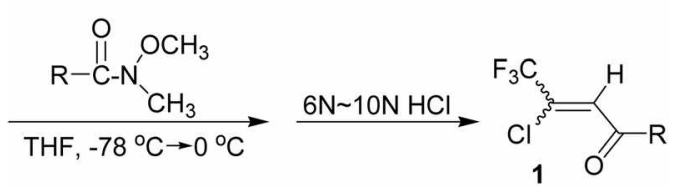

\begin{tabular}{|c|c|c|c|}
\hline Compound No. & $\mathrm{R}$ & Yield $(\%)^{4}$ & $E Z^{b}$ \\
\hline 1a & & 95 & $54 / 56$ \\
\hline 1b & & 92 & $54 / 46$ \\
\hline $1 c$ & & 94 & $50 / 50$ \\
\hline $1 d$ & & 94 & $54 / 46$ \\
\hline 1e & & 92 & $55 / 45$ \\
\hline $1 \mathrm{f}$ & & 94 & $55 / 45$ \\
\hline $1 g$ & & 92 & $53 / 47$ \\
\hline $1 \mathrm{~h}$ & & 95 & $54 / 46$ \\
\hline $1 \mathrm{i}$ & & 90 & $54 / 46$ \\
\hline $1 \mathbf{j}$ & & 92 & $53 / 47$ \\
\hline $1 \mathrm{k}$ & & 90 & $54 / 46$ \\
\hline 11 & & 93 & $52 / 48$ \\
\hline $1 \mathrm{~m}$ & & 88 & $54 / 46$ \\
\hline 1n & & 90 & $50 / 50$ \\
\hline 10 & & 81 & $54 / 46$ \\
\hline
\end{tabular}

Tsolated yield. ${ }^{\circ} E Z$ ratio was determined by ${ }^{19} F$ NMR spectroscopv:

Since trifluoropropynyllithium can also be generated from 2-bromo-3.3.3-trifluoropropene. ${ }^{12}$ we examined the hydrochlorination reaction of [I]. Therefore. the reaction of 2bromo-3,3.3-trifluoropropene (1 equiv) with LDA ( 2 equiv) at $-78^{\circ} \mathrm{C}$ afforded trifluoropropynyllithiunt which was reacted with Weiureb benzanide to give intermediate [I]. However. the treatment of intermediate [I] with $6 \mathrm{~N} \mathrm{HCl}$ resulted in the formation of $2 a$ in $80 \%$ yield. Previous literature ${ }^{1]}$ showed that treatment of [I] with $\mathrm{H}_{2} \mathrm{O}$ in the presence of diisopropylamine resulted in the formation of enaminone 3a exclusively. Enaminone 3a was easily hydrolyzed to give $2 \mathbf{a}$ at room temperature under $6 \mathrm{~N} \mathrm{HCl}$ condition. whereas enaminone 3 b was hydrolyzed to give $2 \mathrm{a}$ at $60^{\circ} \mathrm{C}$ for $5 \mathrm{~h}$ under 6 $\mathrm{N} \mathrm{HCl}$ condition. Therefore. a plausible mechanism for the formation of $2 a$ in this reaction may involve the addition reaction of disopropylamine formed in the reaction process towards ynone [II] to give enaminone 3a which was easily hỵdrolyzed under acidic condition.<smiles>CON(C)[C@H](C(=O)c1ccccc1)/C(=C/C(=O)c1ccccc1)C(F)(F)F</smiles>

A typical reaction procedure for the preparation of $1 \mathrm{c}$ is as follows. A $25 \mathrm{~mL}$ two-neck round bottom flask equipped with a magnetic stirrer bar, a septum and an argon tee colmected to an argon source was charged with $3,3.3-$ trifluoropropyne $(0.564 \mathrm{~g} .6 .0 \mathrm{mmol})$ and $\mathrm{THF}$ at $-78^{\circ} \mathrm{C}$ and then $n-\mathrm{BuLi}(6.0 \mathrm{mmol})$ was added. After the reaction mixture was stirring at $-78^{\circ} \mathrm{C}$ for $30 \mathrm{~min}, 4, \mathrm{~N}$-dimethoxy $-\mathrm{N}$ methylbenzamide $(0.585 \mathrm{~g} .3 \mathrm{~nm}$ ol) was added into the mixture at $-78^{\circ} \mathrm{C}$ and then slowly wanned to $0^{\circ} \mathrm{C}$. followed by quenching with $6 \mathrm{~N} \mathrm{HCl}$. The reaction mixture was extracted with diethyl ether twice. The diethyl ether solution was dried over andyydrous $\mathrm{MgSO}_{4}$ and chromatographed on $\mathrm{SiO}_{2}$ column. Elution with a mixture of hexane and ethyl acetate $(10: 1)$ provided $0.744 \mathrm{~g}$ of $1 \mathrm{c}$ in $94 \%$ yield. $(Z)-1 \mathrm{c}$ : oil: ' $\mathrm{H}$ NMR $\left(\mathrm{CDCl}_{2}\right) \delta 7.91$ (d. $J=8.7 \mathrm{~Hz}, 2 \mathrm{H}$ ). 7.40 (s. IH). $6.99(\mathrm{~d}, J=8.7 \mathrm{~Hz} .2 \mathrm{H}) .3 .90(\mathrm{~s}, 3 \mathrm{H}) ;(E)-1 \mathrm{c}: \delta 7.89(\mathrm{~d}$. $J=8.7 \mathrm{~Hz} .2 \mathrm{H}$ ). 7.00 (s. IH). 6.99 (d. $J=8.7 \mathrm{~Hz}, 2 \mathrm{H}$ ). 3.90 (s. $3 \mathrm{H}):{ }^{19} \mathrm{~F} \mathrm{NMR}\left(\mathrm{CDCl}_{3 .}\right.$ internal standard $\left.\mathrm{CFCl}_{3}\right) \delta-65.67$ (s. 3F, $E$-isomer). -70.40 (s, 3F, $Z$-isomer): $\mathrm{MS}$. $\mathrm{m} / \mathrm{z}$ (relative intensity) $266(\mathrm{M}+2.23) .264\left(\mathrm{M}^{+} .70\right) .238(18) .236(54)$. 135 (100), 107 (12), 92 (14), 77 (I6); IR (neat) 3046. 3020 . 2968. 2940. 2845. 1675. 1598. 1575. 1510, 1462, 1445 , 1260. $1180,1150,834 \mathrm{~cm}^{-1}$. Anal. Calcd for $\mathrm{C}_{10} \mathrm{H}_{6} \mathrm{ClF}_{3} \mathrm{O}: \mathrm{C}$. 50.00: H. 3.05. Found: C. 49.93; H, 2.99.

Acknowledgements. This work was supported by Maeji Institute of Acadenic Research (2004-2005). Yonsei University.

\section{References}

1. Liebman. J. F; Greenberg. A: Dolbier, W. R. Jr. FluorineContaining Molecules: VCH: New York. 1988.

2. Banks. R. E.: Smart. B. E.: Tatlow. I. C. Orgmofhorine Chentisty-Phinciple and Contmercial Applications: Plenum: New York. 1994.

3. Ojima. I.: McCarthy. J. R.: Welch. J. I. Biontedical Frontiers of Fluorine Chemistry, ACS: Washington, DC. 1996.

4. Alvernhe. G.: Langlois. B.: Laurent. A.; Le Drean. I.: Selmi, A. Tetrahedron Lett 1991. 32, 643-646.

5. Alvemhe. G.: Greif. D.: Langlois. B.: Laurent. A.: Le Drean. 1.: Pulst. M.: Selmi. A.: Weissentels. M. Bull. Soc. Chim. Fr. 1994. 131. 167-171.

6. Arnaud, R.; Bensadat, A.: Ghobsi, A.: Laurent, A.: Le Drean. 1:; Lesniak. S.: Selmi. A. Bull. Soc. Chim. Fr: 1994, 131.841-853.

7. Diab. J: Laurent, A.: Le Drean. I. J. Flhorine Chem 1997. 84. 145-147.

8. Okano. I.: Uekawa. I.: Eguchi. S. Bull. Chent Soc. Jpn. 1989. 62. 2575-2579.

9. Selmi. A.: Gaied. M. M. El: Alvernhe. G. J. Flworne Chem. 1995. 72. $1-7$.

10. Nahm. S.; Weinreb. S. M. Tetahedron Lett. 1981, 22.3815-3818.

11. Jeong. I. H.: Teon. S. L.: Min. Y. K.: Kim. B. T. Tetrahedron Lett. 2002. +3. 7171-7174

12. Yamazaki. T.: Mizutani. K.: Kitazume. T. J. Ong. Chem. 1995. 60. $6046-6056$. 